\title{
Micromammal remains from Areni-1 Cave, Armenia
}

\author{
N. Zarikian ${ }^{1}$, B. Gasparyan ${ }^{2}$ \\ ${ }^{I}$ Institute of Archaeology and Ethnography, National Academy science of Republic of Armenia. \\ ${ }^{2}$ Institute of Archaeology and Ethnography, National Academy science of Republic of Armenia.
}

\begin{abstract}
The cave site Areni-1, located in south-eastern Armenia, which has been excavated during 20072013, yielded rich assemblages of micromammal remains from the Late Chalcolithic and Medieval sequences. In this research the tooth remains of found micromammals are reported.The tooth remains belong to (3) orders including; 1) Order Rodentia: fam. Muridae, fam. Cricetidae, fam. Gerbillidae, fam. Arvicolidae, fam. Dipodidae, fam. Soricidae and fam. Sciuridae. 2) Order Lagomorpha: fam. Ochotonidae 3) Order Chiroptera.Presented research in based on morphologic and morphometric methods using modern comparative neontological specimens of the osteological collection in NAS RA Institute of Zoology.Based on this study, paleoenvironmental aspects in Areni have been discussed, showing that the environmental interpretations drawn from the Areni- 1 cave rodents are based on the use of modern analogues and the assumption that ecological requirements and/or behavior have remained constant for both the rodents and the accumulating agency.
\end{abstract}

Key words: Areni, Chiroptera, Lagomorpha, micromammals, paleoenvironment, Rodentia, tooth remains.

\section{INTRODUCTION}

In this study, rodent and lagomorph assemblages from Areni-1 cave located in south-eastern Armenia were studied. Since caves and rock shelters are used as shelters by animals including predators and scavengers, they often contain the remains of these animals and their food and hence fossil and remains evidence of past animal populations (Burke and Cinq-Mars, 1996; Heaton et al., 1996). The main aspects of the archaeological records of pellets from micromammals in archeological studies are that it can represent the linkage between zoology and archaeology (Chaline1972, Andrews1990, Darvish, 1992, Darvish et al., 2000). The results of taxonomic identification and quantification and distribution of these remains prove that the rodent remains, are useful in paleontology and archaeology, because of their abundance in fossil remains also for data preparing in continental remains by rodents biostratigraphy. Also, the rodent remains hold the greatest potential for archaeologists for monitoring palaeoenviroments because they are more sensitive to changes in the local environments of an archaeological site than are larger mammals (Redding, 1978). An abundant literature is now available about the ecology (Gårding, 2000; Lindström et al., 2001), development (Salazar-Ciudad \& Jernvall, 2001) and biogeography and identification of palaeoenviroment of each taxon.We carried out a detailed taphonomic analysis of the Rodent, Lagomorha and Chiroptera remains in order to understand the taphonomic imprints in this assemblage. A taphonomic analysis permits us to discover the recorded digestion, breakage and burnt of specimens and also the age of this assemblage. Our taphonomic study by scanning microscope confirms also that the rodent remains displayed generally the fractures and corrosion marks which are the typical signs of predation (Andrews, 1990). In addition, this research was performed on the basis of morphologic and morphometric methods and comparison with modern osteological collections. The key of determination of rodents species are from (Corbet, 1978, Harrison et al., 1991, Shidlovski, 1976), which is a faunal adjusted key of Caucasia rodents and the classification of Rodentia (Wilson and Reeder, 2005).

\section{MATERIALS AND METHODS}

Areni Cave-1 is located in Vayots Dzor region, near the tributary of the Arpa River Gnishik: at $30 \mathrm{~m}$ height. 110km far from Yerevan, stablished in IV mil. BC (Fig.1,2). It is situated just behind the riverside restaurant, in the rock (on the right, when turning to the gorge). The cave comprises a range of spaces, hewn in the rock, linked with narrow aisles. In the upper parts of the cliff it has several holes of fewer diameters. The exit is partially covered with large stones. This cave belongs to clastocarstic caves, because it originated in limestone conglomerates. Since 2007 archaeological researches have been held here. As a result, materials dating back to 4200-3500 BC were found: plant residues, crockery, grape and apricot kernels, pieces of cloth, knitted of reed, women jewelry, part of the mummified goat body and many animal bones. 


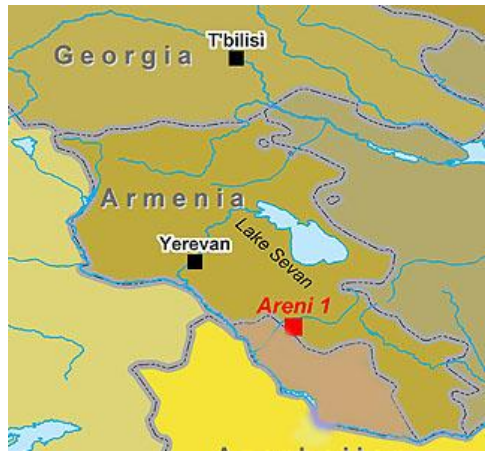

Figure 1 Areni location

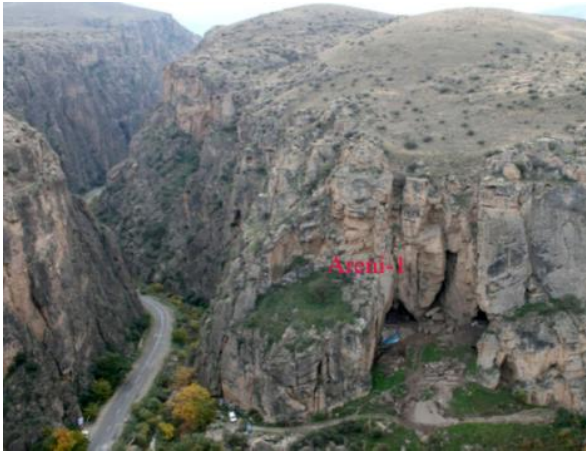

Figure 2 Areni-1 cave

The picked remains were belonging to four trenches in Areni-1 cave (Fig. 3). A great number of remains were collected after the systematic dry sieving of the sediments from the Cave. The remains mainly belong to the different families of rodents and a small part of specimens belong to Lagomorphs and Chiropteras. The zooarchaeological material contained cranial and post cranial parts were sorted anatomically and then washed with HCL (5\%). The preservation conditions are unequal according to different localities. Measurements of the material were made with the aid of measuring microscope with accuracy $0.001 \mathrm{~mm}$. In addition, their morphological features were investigated by stereomicroscope. All recovered fragments were measured when possible. . The identification of Rodentia was based on the teeth and sometimes on all elements.

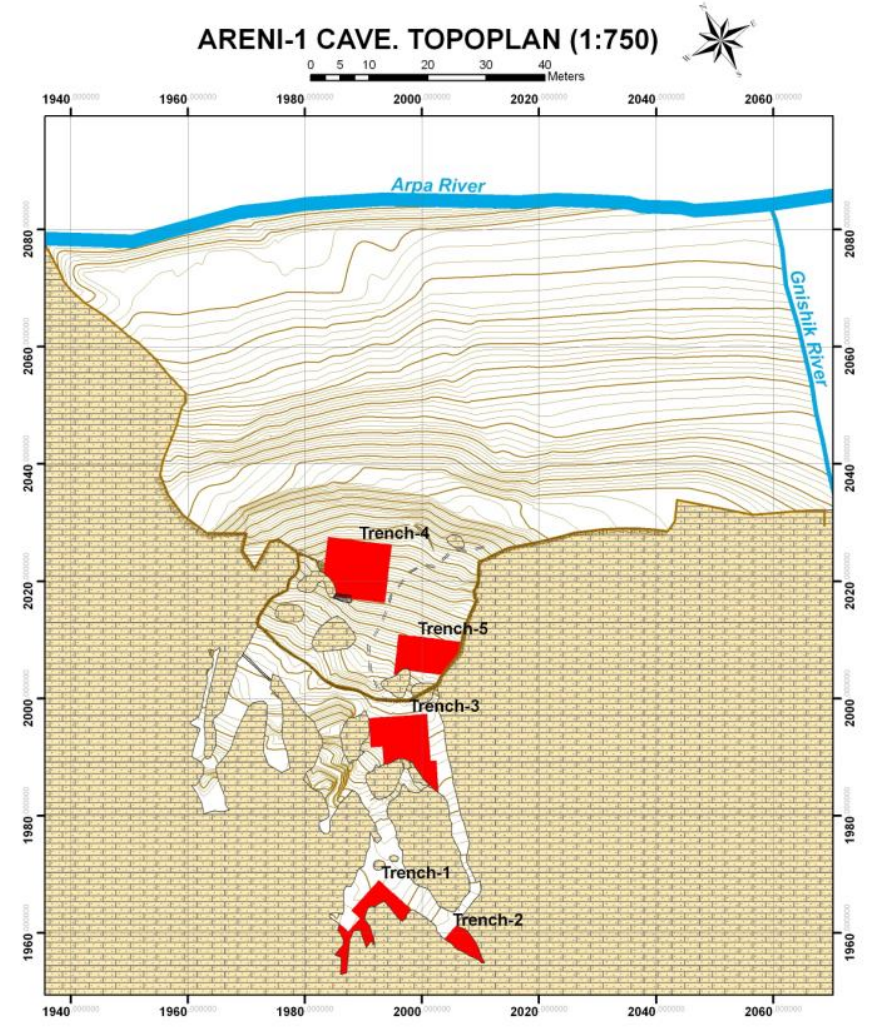

Figure 3. Areni-1 cave topoplan

\section{RESULT AND DISCUSSION}

The density of the remains was different in each trench. Approximately 13 species remains have been recovered so far, mainly belonging to the order Rodentia but also including remains of order Lagomorpha and Chiroptera. The list of the identified specimens is reported in Table1. The species belong to different ecological niches which can provide a picture of the past landscapes around the site.

Factors such as physiological tolerance, food resources, competition, predation and sheltering conditions seriously affected the local distribution of rodent species and feed us important information paleoenviroment of the site. 
Table.1. Species composition of the micromammals from Areni-1 Cave

\begin{tabular}{|c|c|c|c|c|c|c|c|c|c|}
\hline Taxa & $\begin{array}{l}\text { Common } \\
\text { name }\end{array}$ & T1 & T2 & T3 & T4 & MNI & NISP & NISP\% & $\begin{array}{l}\text { Density } \\
/ \mathrm{m}^{2}\end{array}$ \\
\hline $\begin{array}{l}\text { Order } \\
\text { Rodentia }\end{array}$ & & & & & & & & & \\
\hline $\begin{array}{l}\text { fam. } \\
\text { Arvicolidae }\end{array}$ & & & & & & & & & \\
\hline $\begin{array}{l}\text { Ellobius } \\
\text { lutescens }\end{array}$ & Mole-vole & - & + & + & + & 5 & 9 & 7.25 & 0.04 \\
\hline $\begin{array}{l}\text { fam. } \\
\text { Cricetidae }\end{array}$ & & & & & & & & & \\
\hline $\begin{array}{l}\text { Cricetulus } \\
\text { migratorius }\end{array}$ & $\begin{array}{l}\text { Migratory } \\
\text { hamester }\end{array}$ & + & + & + & - & 10 & 14 & 11.29 & 0.06 \\
\hline $\begin{array}{l}\text { Cricetus } \\
\text { cricetus }\end{array}$ & $\begin{array}{l}\text { Common } \\
\text { hamster }\end{array}$ & - & - & + & - & 2 & 3 & 2.41 & 0.01 \\
\hline $\begin{array}{l}\text { Mesocricetus } \\
\text { auratus }\end{array}$ & $\begin{array}{l}\text { Golden } \\
\text { hamster }\end{array}$ & - & + & + & - & 9 & 15 & 12.09 & 0.06 \\
\hline
\end{tabular}

fam.

Dipodidae

\begin{tabular}{|c|c|c|c|c|c|c|c|c|c|}
\hline $\begin{array}{l}\text { Allactaga } \\
\text { elater }\end{array}$ & $\begin{array}{l}\text { Small } \\
\text { five-toed } \\
\text { jerboa }\end{array}$ & - & + & + & - & 12 & 20 & 16.12 & 0.08 \\
\hline \multicolumn{10}{|l|}{$\begin{array}{l}\text { fam. } \\
\text { Gerbillidae }\end{array}$} \\
\hline $\begin{array}{l}\text { Microtus } \\
\text { sp. }\end{array}$ & vole & + & + & + & - & 15 & 20 & 16.12 & 0.078 \\
\hline $\begin{array}{l}\text { Meriones } \\
\text { tristrami }\end{array}$ & $\begin{array}{l}\text { Tristram's } \\
\text { jird }\end{array}$ & - & + & + & - & 3 & 8 & 6.45 & 0.03 \\
\hline \multicolumn{10}{|l|}{ fam. Muridae } \\
\hline $\begin{array}{c}\text { Mus } \\
\text { musculus }\end{array}$ & $\begin{array}{l}\text { House } \\
\text { mouse }\end{array}$ & - & + & + & - & 3 & 4 & 3.22 & 0.01 \\
\hline $\begin{array}{l}\text { Apodemus } \\
\text { sylvaticus }\end{array}$ & $\begin{array}{l}\text { Common } \\
\text { field } \\
\text { mouse }\end{array}$ & - & + & - & - & 1 & 4 & 3.22 & 0.01 \\
\hline
\end{tabular}

fam.

Sciuridae

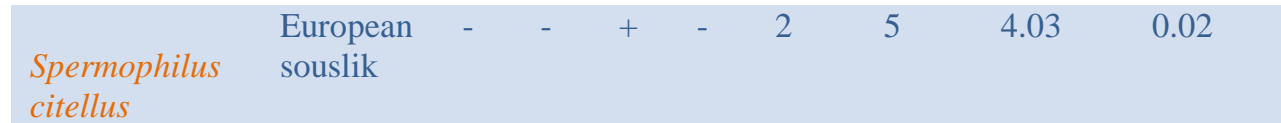

\section{Order}

Soricomorpha

fam.

Soricidae

$\begin{array}{lllllllll}\text { Crocidura White- } & - & - & + & - & 1 & 2 & 1.61 & 0.008\end{array}$

suaveolens

teeth

shrew

Order

Lagomorpha

fam.

Ochotonidae

Ochotona

rufescens

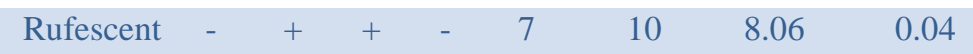

Pika

Order

Chiroptera

\begin{tabular}{|c|c|c|c|c|c|c|c|c|}
\hline 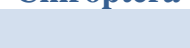 & - & + & + & - & 3 & 10 & 8.06 & 0.04 \\
\hline Total & & & & & 73 & 124 & & \\
\hline
\end{tabular}


The occurrence of micromammals in fossil deposits owes mainly to birds of prey or mammalian carnivores (Canidae, Mus- telidae). Particularly, nocturnal birds of prey (owls) regurgitate rather well-preserved bone and teeth. The dietary spectrum of these animals consists of up to $90 \%$ of micromammals. Although owls (especialy Eurasian eagle-owl) and presumably other predators are capable of bearing prey some $20 \mathrm{~km}$ from their source the evidence was the owl bones remains in Areni-1 also confirmed by the fractures and corrosion marks on some bones. The Armenia's animal biodiversity determined that most faunal remains discovered in Areni Cave originated within a radius of about $5-10 \mathrm{~km}$ from the cave entrance. Thus, one might reasonably assume that most small animals preserved at Areni were taken close to the cave.The paleoecological analysis referred rodents remains recorded in Armenia to particular living spaces (rock, grassland, moist steppe, woodland, sand dunes). Of the species recorded at Areni the following can be referred to as grassland dwellers: C. migratorius, Meriones tristrami (fig.12), Microtus sp. (M. arvalis) (fig6), Ellobius lutescens (fig.10) (also refers to a height700-2500m) and Spermophilus citellus (fig.13). Woodland dwellers is Apodemus sylvaticus (fig. 9) and meadow dweller is Mus musculus (fig.11), while Crocidura suaveolens (fig.7) preferred habitat is scrub and gardens and Ochotona rufescens (fig.8) occurs in mountainous regions. This suggests the existence of a mosaic of habitats in the vicinity of Areni Cave. The species Allactaga elater has the biggest value of MNI (12) and NISP (20) (Fig. 4) A. elater lives in areas with sparse and dense vegetation which consist of various kinds of halophytes, such as Alhagi camelorum, Artemisetum, Halocmemum, Halostachys, Halidium and Salsoletum verrucosae. Also fed on wheat and sunflower seeds, green parts of various plants (trifolium, graminae), apple, carrot and drunken water. Which is matches the archaeobotanical remains of Areni-1 cave (Smith, et al.2014).A. elater shares its environment with another rodent species (ÇOLAK, et al. 1997); Meriones tristrami, Mus musculus, Cricetulus migratorius and Mesocricetus auratus (fig.5). M. auratus is the most abundant species co-occurring with A. elater.The density of rodent's taxa in Areni-1 cave (table 1.) suggests that this population of rodents probably found food on this site on a regular basis, as would be the case with an agricultural community.

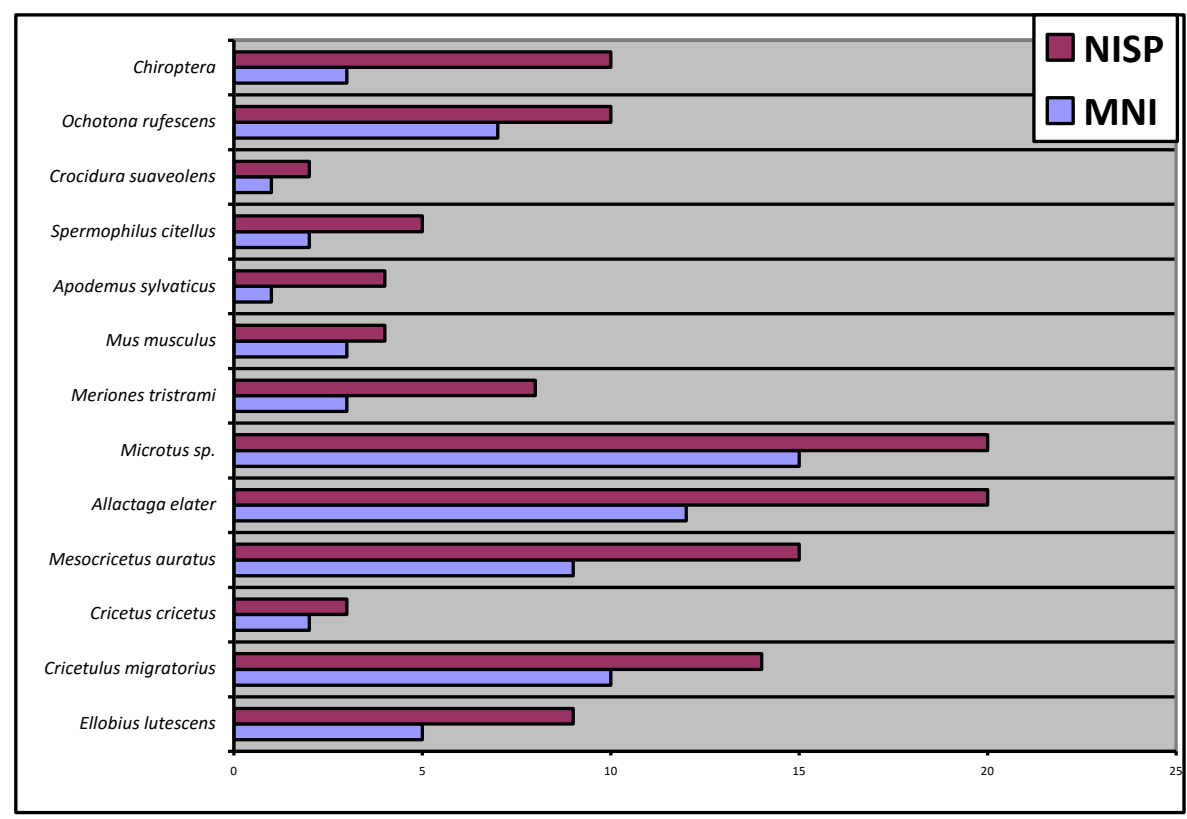

Figure 4 MNI of Areni-1 cave species remains.

Thus, the environmental interpretations drawn from the Areni-1 cave rodents are based on the use of modern analogues and the assumption that ecological requirements and/or behavior have remained constant for both the rodents and the accumulating agency. The Areni's rodent fauna comprises taxa that prefer different but often overlapping microhabitats. These include riverine thickets, woodlands, and grasslands. Because Gerbillinae as a group is an indicator of open conditions, while Murinae are typically considered to be more abundant in closed environments (Dauphin et al., 1994; Denys et al., 1996), the higher representation of taxa allied to the latter group at Areni-1cave suggest, that forested and mesic micro-environments dominated over open grassland/woodland habitats. By and large, all the rodent genera from Areni are extant and these provide some of the earliest appearances of the genera in Armenia and Caucasia. 


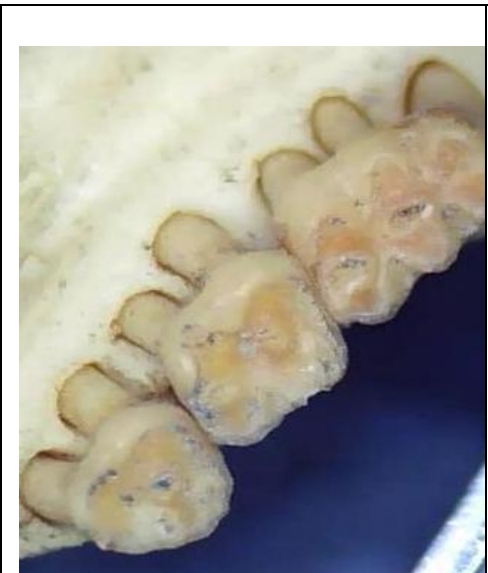

Figure 5 Mesocricetus auratus teeth

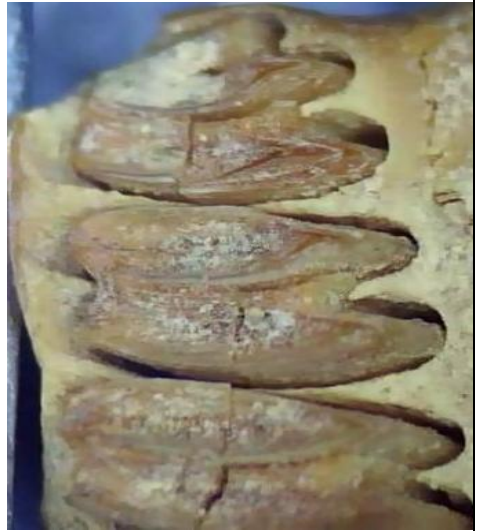

Figure 8 Ochotona rufescens teeth

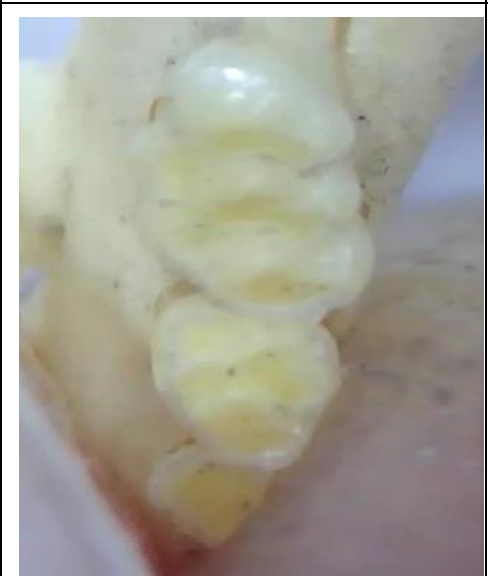

Figure 11 Mus musculus

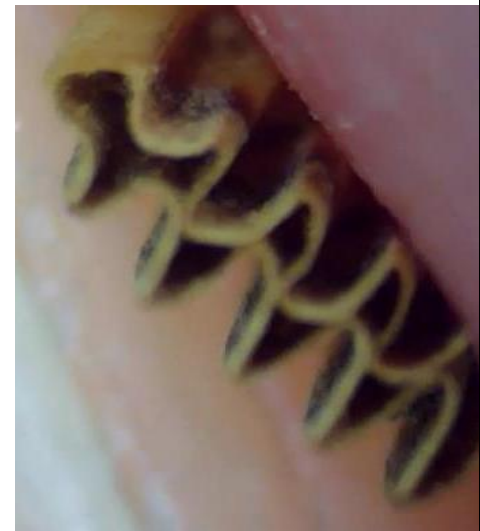

Figure 6 Microtus $s p$. teeth

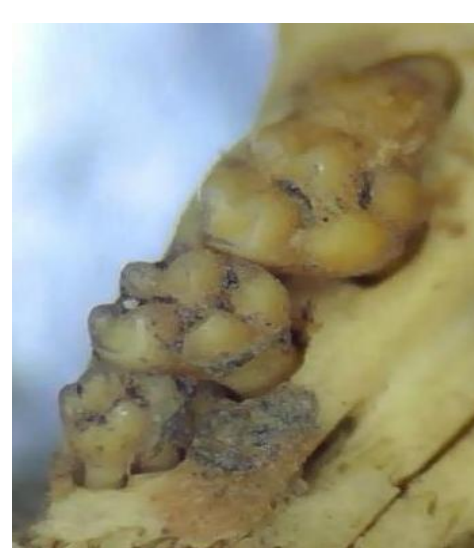

Figure 9 Apodemus sylvaticus teeth

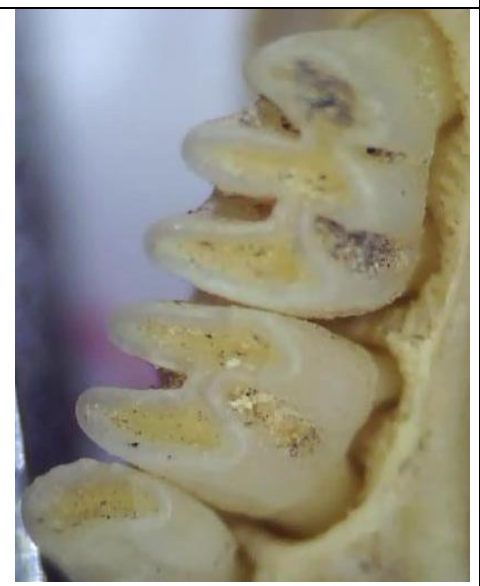

Figure 12 Meriones tristrami

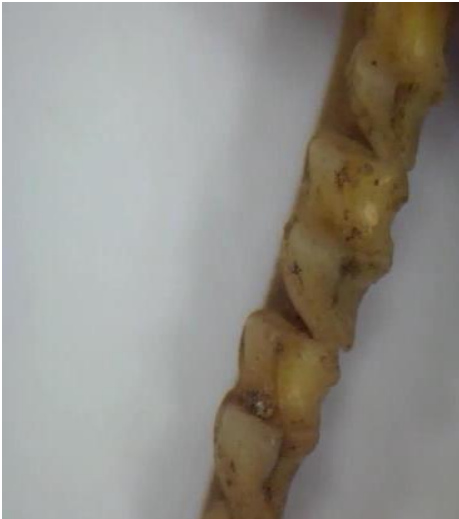

Figure 7 Crocidura suaveolens teeth

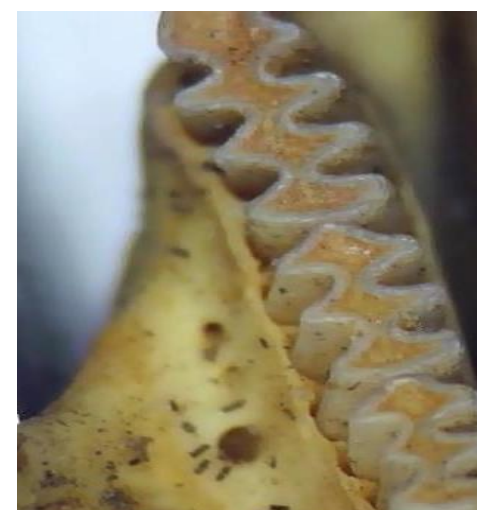

Figure 10 Ellobius lutescens teeth

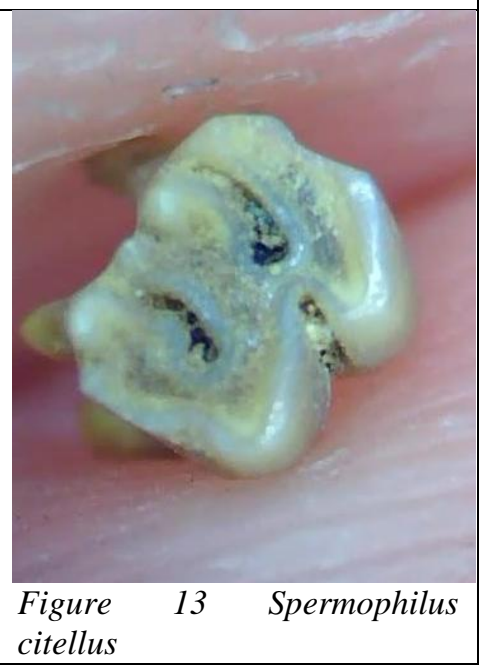

\section{REFERENCES}

[1] Adamian M. S., Klem D. Jr. Field guide to the birds of Armenia. Oakland, 1997, AUA Press.

[2] Adamian M. S., Klem D. Jr.Handbook of the birds of Armenia. Oakland, 1999, AUA Press.

[3] Andrews P. Owls, Caves and Fossils .University of Chicago Press, Chicago, 1990.

[4] Burke A., Cinq-Mars J. Dental characteristics of Late Pleistocene Equus lambei from the Bluefish Caves, Yukon Territory, and their comparison with Eurasian horses, 1996. Géographie physique et Quaternaries $50: 81-93$. 
[5] Chaline J. Les rongeurs du Pleistocene moyen et superieur de France.- Cahiers de Paleontologie du CNRS, 1972. Paris, 410 pp.

[6] Çolak E., Kıvanç E., Yiğit, N. Taxonomic Status and Karyology of Allactaga elater aralychensis Satunin, 1901 (Rodentia: Dipodidae) in Turkey, (1997b). Turkish Journal of Zoology. 21: 355-360. [In Turkish]

[7] Corbet, G.B. The mammals of the Palaearctic region. A taxonomic review. British Museum of Natural History London, 1978, pp.314.

[8] Dahl S.K. Fauna of the Armenian SSR. vol. I. Vertebrates. Yerevan, Publishing House of the Academy of Sciences of the Armenian SSR, 1954. 415 p. [in Russian]

[9] Darvish J., Ghieasi A., Khosravi M. Identification of rodents remaines in Robat sharaf of Sarakhs (Khorassan) by the aid of morphological and neontological study, Journal of Science, Alzahra University, 2000, Vol.12, No.1, p.31-44.

[10] Darvish,J. Preliminary study of the fauna of rodents in the Northern Khorassn with the aid of pellets from the prey birds, Pests and plant diseases magazine, 1992,Vol.59, No.1,2, P.33-43.

[11] Denys C., Williams C.T., Dauphin Y., Andrews P., Ferndandez-Jalvo Y. Diagenetical changes in Pleistocene small mammal bones from Olduvai Bed I. Palaeogeography, Palaeoclimatology, Palaeoecology, 1996.

[12] Dubois-Dauphin M., Frankowski H., Tsujimoto Y., Huarte J., Martinou J.C. Neonatal motoneurons overexpressing the Bcl-2 protooncogene in transgenic mice are protected from axotomy-induced cell death, 1994. Proc Natl Acad Sci USA 91:2459-2463.

[13] Garding L. A simple model for interplay of predators, rodents and foot. Journal of Theoretical Biology, 2000, 206: 73-80.

[14] Gromov I.M., Erbaeva M.A. 1995. Mammals of Russia and adjacent territories. Lagomorphs and rodents (ed. A. Aristov and GI Baranova). St. Petersburg, Zool. Institute of Russian Academy of Sciences, 1995. 552. [in Russian]

[15] Harrison D.L., Bates P.J.J. The mammals of Arabia. Harrison Zoological Museum Publ. Sevenoaks 1991.

[16] Heaton T.H., Talbot S.L., Shields G. An ice age refugium for large mammals in the Alexander Archipelago, southeastern Alaska, 1996. Quaternary Research 46:186 - 192.

[17] Kalantaryan M.A. 1952. New data about porcupine in Armenia, Academy of Sciences of the Armenian SSR, vol. 5, №4, 1952. [in Russian]

[18] Lindstrom J., Ranta E., Kkko H., Lundberg P., Kaitala V. From arctic lemmings to adaptive dynamics: Charles Elton's legacy in population ecology, 2001. Biological Reviews 76: 129-158.

[19] Pavlinov I.J. Systematics of modern mammals.Studies on the fauna. M., 2003. 293. [in Russian]

[20] Redding W. R. Rodents and the archaeological palaeoenvironment: Considerations, problems and future. Approaches to faunal analysis in the Middle East. R. H. Meadow and M. A. Zeder Harvard, Peabody Museum of Archaeology and Ethnology, 1978. Peabody Museum Bulletin 2:63-68.

[21] Sahakyan L.V. Some of the environmental issues and the current state of the populations of Asia Minor ground squirrel Spermophilus xanthoprymnus (Bennett, 1835) in Armenia. 2006. Bull. Moscow Society of Naturalists, Dep. biol, t 3, number 5:.. 65-68. [in Russian]

[22] Salazar-Ciudad I., Jernvall J. A gene network model accounting for development and evolution of mammalian teeth. Proceedings of the National Academy of Sciences, USA, 2002, 99:8116-8120.

[23] Sidlovskij M.V. Opredelitel gryzunov zakavkazja. Akademij a nauk Gruzinkoj SSR, 1976, Tbilisi.

[24] Smith A., Bagoyan T., Gabrielyan I., Pinhasi R., Gasparyan B. Late Chalcolithic and Medieval Archaeobotanical Remains from Areni-1 (Birds' Cave), Armenia, in B. Gasparyan and M. Arimura (Eds.), Stone Age of Armenia, A Guide-book to the Stone Age Archaeology in the Republic of Armenia, 2014.

[25] Wilson D. E. \& Reeder D. M. (editors) Mammal Species of the World. A Taxonomic and Geographic Reference (3rd ed), 2005. Johns Hopkins University Press, 2,142 pp. (Available from Johns Hopkins University Press, 1-800-537-5487 or (410) 516-6900, or at http://www.press.jhu.edu). 